\title{
PENGARUH INTELLECTUAL CAPITAL TERHADAP KINERJA \\ KEUANGAN PERUSAHAAN \\ (Studi Empiris Pada Perusahaan Manufaktur yang Terdaftar di BEI)
}

\author{
Ronny Malavia Mardani \\ Jurusan Akuntansi Fakultas Ekonomi Universitas Islam Malang \\ No Telepon: 08125252827
}

\begin{abstract}
The objective of this study is to analyze the influence of Intellectual Capital to Corporate Finance Performance. Based on the result of this study, show that : a) There is a positive influence of Intellectual capital (VACA, VAHU, and STVA) to the company's financial performance (Return on Equity, Return on Total Assets, Asset Turn Over, and Growth Revenue).; b) There is a positive influence of Intellectual capital (Vaca, VAHU, and STVA) to the future of company's financial performance, and c) There is a positive influence of average growth of the Intellectual Capital to the future company's financial performance..
\end{abstract}

Keywords: Intellectual capital, Financial Performance

\section{PENDAHULUAN}

Perkembangan dalam bidang ekonomi membawa dampak perubahan yang cukup signifikan terhadap pengelolaan suatu bisnis dan penentuan strategi bersaing. Para pelaku bisnis mulai menyadari bahwa kemampuan bersaing tidak hanya terletak pada kepemilikan aktiva berwujud, tetapi lebih pada inovasi, sistem informasi, pengelolaan organisasi dan sumber daya manusia yang dimilikinya. Oleh karena itu, organisasi bisnis semakin menitikberatkan akan pentingnya knowledge asset (aset pengetahuan) sebagai salah satu bentuk aset tak berwujud (Agnes, 2008). Bahkan Starovic et al. (2003) menemukan bahwa pengetahuan telah menjadi mesin baru dalam pengembangan suatu bisnis.

Munculnya "new economy", yang secara prinsip didorong oleh perkembangan teknologi informasi dan ilmu pengetahuan, juga telah memicu tumbuhnya interes dalam intellectual capital (IC) (Petty and Guthrie, 2000; Bontis, 2001). Salah satu area yang menarik perhatian baik akademis maupun praktisi adalah yang terkait dengan kegunaan IC sebagai salah satu instrument untuk menentukan nilai perusahaan (Stewart, 1997; Edvinsson and Malone, 1997; Sveiby, 2001). Hal ini telah menjadi vexed issue, dimana beberapa penulis telah mensugestikan bahwa manajemen dan sistem pelaporan yang telah mapan selama ini secara berkelanjutan kehilangan relevansinya karena tidak mampu menyajikan informasi yang esensial bagi eksekutif untuk mengelola proses yang berbasis 
pengetahuan (knowledge-based processes) dan intangible resources (Bornemann and Leitner, 2002).

Meningkatnya perbedaan antara nilai pasar dan nilai buku perusahaan telah menarik para peneliti untuk menyelidiki nilai yang hilang (hidden value) pada laporan keuangan perusahaan. Lev (2001) dalam Chen et al. (2005) mencatat bahwa selama tahun 1977 2001, dalam US Standard and Poors (S \& P) 500, rasio nilai pasar terhadap nilai buku perusahaan meningkat dari 1 sampai 5. Hal ini menunjukkan secara tidak langsung bahwa sekitar $80 \%$ nilai pasar perusahaan tidak tercermin dalam laporan keuangan. Menurut Edvinsson dan Malone (1997) dalam Chen et al (2005), perbedaan antara nilai pasar dan nilai buku perusahaan adalah nilai Intellectual Capital (IC). IC menurut Organisation for Economic Cooperation and Development (OECD, 1999) dijelaskan sebagai nilai ekonomi dari dua kategori aset tidak berwujud, yaitu organizational (structural)capital dan human capital. Organizational (structural) capital adalah sistem software, jaringan distribusi, dan rantai pasokan. Human capital meliputi sumber daya manusia di dalam organisasi (karyawan) dan sumber daya eksternal yang berkaitan dengan organisasi seperti konsumen dan supplier.

Ulum, Ghozali dan Chariri (2008) menyatakan bahwa pada umumnya IC diidentifikasi sebagai perbedaan antara nilai pasar perusahaan dan nilai buku aset perusahaan tersebut. Menurut Roslender dan Fincham (2004) dalam Ulum, Ghozali dan Chariri (2008) hal ini didasarkan observasi bahwa sejak akhir 1980-an, nilai pasar dari bisnis kebanyakan dan secara khusus bisnis yang berdasarkan pengetahuan telah menjadi lebih besar dari nilai yang dilaporkan dalam laporan keuangan. Edvinsson dan Malone (1997) dalam Chen et.al.(2005) mengungkapkan bahwa IC adalah nilai yang tersembunyi (hidden asset) dalam perusahaan. Yang dimaksud dengan hidden asset disini adalah bahwa intellectual capital tidak terlihat seperti aset fisik lainnya dan juga aset intelektual ini tidak tercermin dalam laporan keuangan perusahaan.

Di Indonesia, fenomena IC mulai berkembang terutama setelah munculnya PSAK No. 19 (revisi 2000) tentang aktiva tidak berwujud. Meskipun tidak dinyatakan secara eksplisit sebagai IC, namun lebih kurang IC telah mendapat perhatian. Menurut PSAK No. 19, aktiva tidak berwujud adalah aktiva non moneter yang dapat diidentifikasi dan tidak mempunyai wujud fisik serta dimiliki untuk digunakan dalam menghasilkan atau menyerahkan barang atau jasa, disewakan kepada pihak lainnya, atau untuk tujuan administratif (IAI, 2002). 
Meningkatnya pengakuan IC dalam mendorong nilai dan keunggulan kompetitif perusahaan, pengukuran yang tepat terhadap IC perusahaan belum dapat ditetapkan. Misalnya, Pulic (1998; 1999; 2000) tidak mengukur secara langsung IC perusahaan, tetapi mengajukan suatu ukuran untuk menilai efisiensi dari nilai tambah sebagai hasil dari kemampuan intelektual perusahaan (value added intellectual coefficient-VAICTM). Komponen utama dari VAIC ${ }^{\mathrm{TM}}$ dapat dilihat dari sumber daya perusahaan, yaitu physical capital (VACA-value added capital employed), human capital (VAHU-value added human capital), dan structural capital (STVA-structural capital value added).

Chen et al. (2005) menggunakan model Pulic (VAIC ${ }^{\text {TM}}$ ) untuk menguji hubungan antara IC dengan nilai pasar dan kinerja keuangan, dimana hasilnya menunjukkan bahwa IC berpengaruh secara positif terhadap nilai pasar dan kinerja perusahaan. Sementara penelitian yang dilakukan Tan et al. (2007) di Bursa Efek Singapore menunjukkan bahwa IC (VAIC ${ }^{\mathrm{TM}}$ ) berhubungan secara positif dengan kinerja perusahaan. Selain itu, penelitian ini mengindikasikan bahwa kontribusi IC (VAICTM) terhadap kinerja perusahaan berbeda berdasarkan jenis industrinya. Temuan Tan et al. (2005) tersebut selaras dengan penelitian Bontis (2001) dan Belkaoui (2003) yang menyatakan bahwa IC (VAICTM) berpengaruh positif terhadap kinerja keuangan perusahaan.

Penelitian mengenai modal intelektual dalam konteks Indonesia menjadi sangat menarik karena berdasarkan survei global yang dilakukan Taylor and Associates pada tahun 1998 dalam Williams (2001) ternyata isu-isu mengenai pengungkapan modal intelektual merupakan salah satu dari sepuluh jenis informasi yang dibutuhkan pemakai.

Berdasarkan latar belakang tersebut, yang menjadi rumusan masalah dalam penelitian ini adalah: Bagaimana Pengaruh Intellectual Capital (physical capital, human capital, dan structural capital) terhadap Kinerja Keuangan Perusahaan (return on equity, return on total assets, asset turn over, dan growth revenue)?

\section{INTELLECTUAL CAPITAL (IC)}

Klein dan Prusak dalam Ulum, Ghozali dan Chariri (2008) memberikan definisi awal tentang IC. Menurut mereka intellectual capital adalah "material yang disusun, ditangkap, dan digunakan untuk menghasilkan nilai asset yang lebih tinggi”. Roos et al. (1997) dalam Ulum, Ghozali dan Chariri (2008) menyatakan bahwa “ IC includes all the processes and the assets which are not normally shown on the balance -sheet and all the intangible assests (trademarks, patent and brands) which modern accounting methods consider...". 
Namun, menurut Bontis et al. (2000) dalam Ulum, Ghozali dan Chariri (2008) menyatakan bahwa pada umumnya para peneliti membagi IC menjadi tiga komponen, yaitu: human capital (HC), structural capital (SC), dan customer capital (CC). Selanjutnya menurut Bontis et al. (2000), secara sederhana HC mencerminkan individual knowledge stock suatu organisasi yang dipresentasikan oleh karyawannya. HC ini termasuk kompetensi, komitmen dan loyalitas karyawan terhadap perusahaan.

\section{VALUE ADDED INTELLECTUAL COEFFICIENT (VAIC ${ }^{\mathrm{TM}}$ )}

Metode VAIC ${ }^{\text {TM}}$, dikembangkan oleh Pulic (1998), didesain untuk menyajikan informasi tentang value creation efficiency dari asset berwujud (tangible asset) dan asset tidak berwujud (intangible asset) yang dimiliki perusahaan. Model ini dimulai dengan kemampuan perusahaan untuk menciptakan value added (VA). VA adalah indikator paling objektif untuk menilai keberhasilan bisnis dan menunjukkan kemampuan perusahaan dalam penciptaan nilai (value creation) (Pulic, 1998). VA dihitung sebagai selisih antara output dan input (Pulic, 1999).

Outputs (OUT) merepresentasikan revenue dan mencakup seluruh produk dan jasa yang dijual di pasar. Inputs (IN) mencakup seluruh beban yang digunakan dalam memperoleh revenue. Hal penting dalam model ini adalah bahwa beban karyawan (labour expenses) tidak termasuk dalam IN. Karena peran aktifnya dalam proses value creation, intellectual potential (yang direpresentasikan dengan labour expenses) tidak dihitung sebagai biaya. Karena itu, aspek kunci dalam model Pulic's adalah memperlakukan tenaga kerja sebagai entitas penciptaan nilai (value creating entity). Hasilnya adalah bahwa VA mengekspresikan the new created wealth of a period.

VA dipengaruhi oleh efisiensi dari Human Capital (HC) dan Structural Capital (SC). Hubungan lainnya dari VA adalah capital employed $(C E)$, yang dalam hal ini dilabeli dengan value added capital employed (VACA). VACA adalah indikator untuk VA yang diciptakan oleh satu unit dari physical capital.

Pulic mengasumsikan bahwa jika 1 unit dari CE menghasilkan return yang lebih besar daripada perusahaan yang lain, maka berarti perusahaan tersebut lebih baik dalam memanfaatkan CE-nya. Dengan demikian, pemanfaatan CE yang lebih baik merupakan bagian dari IC perusahaan.

Hubungan selanjutnya adalah VA dan HC. 'Value Added Human Capital' (VAHC) menunjukkan berapa banyak VA dapat dihasilkan dengan dana yang dikeluarkan untuk 
tenaga kerja. Hubungan antara VA dan HC mengindikasikan kemampuan dari HC untuk menciptakan nilai di dalam perusahaan. Konsisten dengan pandangan para penulis IC lainnya (Edvinsson, 1997; Sveiby, 1998), Pulic (1998) berargumen bahwa total salary and wage costs adalah indikator dari HC perusahaan.

Rasio terakhir adalah menghitung kemampuan intelektual perusahaan dengan menjumlahkan coefisien-coefisien yang telah dihitung sebelumnya. Hasil penjumlahan tersebut diformulasikan dalam indikator baru yang unik, yaitu VAICTM:

\section{HUBUNGAN MODAL INTELEKTUAL TERHADAP KINERJA KEUANGAN PERUSAHAAN (FINANCIAL PERFORMANCE)}

Kinerja keuangan perusahaan adalah suatu tampilan atau keadaan secara utuh atas keuangan perusahaan selama periode/ kurun waktu tertentu. Kinerja keuangan merupakan gambaran atas kondisi keuangan sebuah perusahaan (Sawir, 2005). Sebagian besar dari hasil - hasil penelitian, seperti misalnya penelitian Tan et al. (2007) dan Chen et al. (2005) menunjukkan bahwa Modal Intelektual/IC berpengaruh positif terhadap kinerja keuangan perusahaan. Perusahaan yang mampu mengelola sumber daya intelektualnya diyakini mampu menciptakan value added serta mampu menciptakan competitive advantage dengan melakukan inovasi, penelitian dan pengembangan yang akan bermuara terhadap peningkatan kinerja keuangan perusahaan. Hal tersebut senada dengan konsep Resource-Based Theory. Sedangkan dari sudut pandang Stakeholder Theory dinyatakan bahwa manajer korporasi akan berusaha memperoleh value added (nilai tambah) yang selanjutnya akan didistribusikan kembali kepada seluruh stakeholder. Oleh karena itu, para stakeholder akan berperan sebagai kontrol dalam rangka penggunaan dan pengelolaan sumber daya perusahaan termasuk sumber daya intelektual.

\section{HIPOTESIS}

Berdasarkan landasan teori dan penelitian terdahulu, maka dapat dirumuskan hipotesis sebagai berikut:

H1: Ada pengaruh positif Intellectual capital (VACA, VAHU, dan STVA) terhadap kinerja keuangan perusahaan (Return on Equity, Return on Total Assets, Asset Turn Over, dan Growth Revenue).

H2: Ada pengaruh positif Intellectual capital (VACA, VAHU, dan STVA) terhadap kinerja keuangan perusahaan masa depan. 
H3: Ada pengaruh positif rata-rata pertumbuhan Intellectual capital terhadap kinerja keuangan perusahaan masa depan.

\section{METODOLOGI PENELITIAN}

\section{Populasi}

Populasi dalam penelitian ini adalah perusahaan manufaktur yang terdaftar di Bursa Efek Indonesia (BEI) periode tahun 2007-2009.

\section{Sampel}

Secara umum diketahui bahwa sampel merupakan bagian dari populasi. Pengambilan sampel dilakukan berdasarkan metode purposive sampling. Metode purposive sampling adalah metode pengumpulan sampel berdasarkan tujuan penelitian.

Adapun kriteria sampel yang digunakan dalam penelitian ini adalah sebagai berikut:

1. Perusahaan manufaktur yang terdaftar di Bursa Efek Indonesia (BEI) periode tahun 2007-2009. Perusahaan manufaktur dipilih untuk tujuan homogenitas sehingga hasil yang bias dapat dihindari. Homogenitas ini penting untuk memastikan bahwa modal intelektual serta ukuran kinerja untuk perusahaan manufaktur tidak terlalu beragam (heterogen), sehingga pengukurannya menjadi lebih objektif.

2. Perusahaan yang mempublikasikan laporan keuangan tahunan berturut-turut dari tahun 2007-2009 dan disajikan dalam bentuk Rupiah.

3. Perusahaan tidak melakukan merger atau akuisisi selama 3 tahun berturut-turut yaitu 2007, 2008 dan 2009. Syarat ini ditetapkan karena merger atau akuisisi dapat mempengaruhi pergerakan harga saham perusahaan.

4. Perusahaan tidak memperoleh laba negatif. Syarat ini ditetapkan karena peneliti memprediksi pengaruh positif intellectual capital terhadap kinerja keuangan perusahaan. Laba negatif akan menyebabkan nilai modal intelektual perusahaan menjadi negatif. Secara logis modal intelektual seharusnya bernilai positif sehingga perusahaan yang memiliki nilai modal intelektual negatif dikeluarkan dari sampel.

5. Perusahaan sampel tidak memperoleh ekuitas negatif selama periode pengamatan. Syarat ini diterapkan karena perusahaan yang memiliki ekuitas negatif mengandung tingkat resiko yang sangat berbeda dengan perusahaan pada umumnya karena kemungkinan mengalami kejadian tertentu atau menghadapi kondisi tertentu sehingga berpotensi mengurangi kualitas simpulan yang akan dihasilkan jika perusahaan tersebut digunakan dalam sampel (Ahmed et al., 2000). 
6. Perusahaan yang tidak disuspen dari perdagangan selama tahun 2007-2009. Perusahaan yang tidak tercatat perdagangan sahamnya untuk keseluruhan tahun tidak dimasukkan ke dalam sampel karena mustahil untuk menentukan abnormal stock return untuk tahun itu.

\section{Definisi Operasional Variabel}

\section{Intellectual Capital}

Intellectual capital adalah perangkat yang diperlukan untuk menemukan peluang dan mengelola ancaman dalam kehidupan. Banyak pakar yang mengatakan bahwa modal intelektual sangat besar peranannya di dalam menambah nilai suatu kegiatan. Berbagai perusahaan yang unggul dan meraih banyak keuntungan adalah perusahaan yang terus menerus mengembangkan sumber daya manusianya (Ross, dkk, 1997).

\section{Value Added Capital Employed (VACA)}

Value Added Capital Employed (VACA) adalah perbandingan antara value added (VA) dengan modal fisik yang bekerja (CE). Rasio ini menunjukkan kontribusi yang dibuat oleh setiap unit dari CE terhadap value added organisasi dengan formula sebagai berikut: $\mathrm{VACA}=\frac{V A}{6 E}$

Dimana:

$\mathrm{VA}=$ Value Added

$\mathrm{CE}=$ Capital Employed : Dana yang tersedia (ekuitas, laba bersih)

\section{Value Added Human Capital (VAHU)}

Value Added Human Capital (VAHU) adalah seberapa besar value added (VA) dapat dihasilkan dengan dana yang dikeluarkan untuk tenaga kerja. Hubungan antara value added (VA) dan human capital (HC) mengindikasikan kemampuan HC membuat nilai pada sebuah perusahaan. Rasio ini menunjukkan kontribusi yang dibuat oleh setiap rupiah yang diinvestasikan dalam HC terhadap value added organisasi. Formulasinya adalah sebagai berikut: $\mathrm{VAHU}=\frac{\mathrm{VA}}{\mathrm{HC}}$

Dimana:

$\mathrm{VA}=$ value added

$\mathrm{HC}=$ Human Capital: beban karyawan.

Beban karyawan dalam penelitian ini menggunakan jumlah beban gaji dan karyawan yang tercantum dalam laporan keuangan perusahaan.

\section{Structural Capital Value Added (STVA)}


Structural Capital Value Added (STVA) adalah Rasio yang mengukur jumlah Structural Capital (SC) yang dibutuhkan untuk menghasilkan 1 rupiah dari VA dan merupakan indikasi bagaimana keberhasilan SC dalam penciptaan nilai. Formulasinya adalah sebagai berikut: STVA $=\frac{s C}{V A}$

Dimana:

$\mathrm{SC}=$ Structural Capital $=\mathrm{VA}-\mathrm{HC}$

$\mathrm{VA}=$ Value Added

\section{Value Added Intellectual Coefficient (VAIC ${ }^{\mathrm{TM}}$ )}

Value Added Intellectual Coefficient (VAICTM) adalah rasio untuk menghitung kemampuan intelektual organisasi dengan menjumlahkan koefisien-koefisien yang telah dihitung sebelumnya.

Formulasi dan tahapan perhitungan VAICTM adalah sebagai berikut:

Tahap I: Menghitung Value Added (VA).

VA dihitung sebagai selisih antara output dan input (Pulic, 1999 dalam Ulum, 2008).

$\mathrm{VA}=\mathrm{OUT}-\mathrm{IN}$

Dimana:

OUT $=$ Output: total penjualan dan pendapatan lain.

IN = Input: beban penjualan dan biaya-biaya lain (selain beban karyawan).

Value Added (VA) juga dapat dihitung dari akun-akun perusahaan sebagai berikut:

$\mathrm{VA}=\mathrm{OP}+\mathrm{EC}+\mathrm{D}+\mathrm{A}$

Dimana:

$\mathrm{OP}=$ operating profit (laba operasi); $\mathrm{EC}=$ employee costs (beban karyawan); $\mathrm{D}=$ depreciation (depresiasi); A = amortization (amortisasi)

Tahap II: Menghitung Value Added Capital Employed (VACA).

Tahap III: Menghitung Value Added Human Capital (VAHU).

Tahap IV: Menghitung Structural Capital Value Added (STVA).

Tahap V: Menghitung Value Added Intellectual Coefficient (VAIC ${ }^{\mathrm{TM}}$ ).

VAIC $^{\text {TM }}$ merupakan penjumlahan dari tiga komponen sebelumnya, yaitu VACA, VAHU, dan STVA (Ulum, 2008). VAIC ${ }^{\mathrm{TM}}=\mathrm{VACA}+\mathrm{VAHU}+\mathrm{STVA}$

\section{Kinerja Keuangan Perusahaan}


Kinerja keuangan perusahaan menggunakan proksi profitabilitas Return on Equity (ROE), Return on Total Assets (ROA), produktivitas Asset Turn Over (ATO), dan Growth Revenue (GR).

a. Return on Equity (ROE)

Return on Equity (ROE) adalah jumlah laba bersih yang dikembalikan sebagai persentase dari ekuitas pemegang saham. ROE diukur dengan rumus: ROE $=\frac{\text { Laba Heraih }}{\text { Ekuitas stakenolaer }}$

b. Return on Total Assets (ROA)

Return on Total Assets (ROA) adalah profitabilitas kunci yang mengukur jumlah profit yang diperoleh tiap rupiah asset yang dimiliki perusahaan. ROA dikalkulasi dengan formula: $\mathrm{ROA}=\frac{\text { LabaBersi } \mathrm{K}}{\text { Total Asaet }}$

c. Asset Turn Over (ATO)

Asset Turn Over (ATO) adalah rasio untuk mengukur kemampuan aset perusahaan untuk memperoleh pendapatan, makin cepat aset perusahaan berputar makin besar pendapatan perusahaan tersebut. Formulasinya adalah: ATO $=\frac{\text { Total Pendapatar }}{\text { Totalasset }}$

d. Growth Revenue (GR)

Growth Revenue (GR) adalah rasio yang mengukur perubahan pendapatan perusahaan. Peningkatan pendapatan biasanya merupakan sinyal bagi perusahaan untuk dapat tumbuh dan berkembang. Formulasinya adalah:

$$
\mathrm{GR}=\left(\frac{\text { Pendapatan Tahun ket }}{\text { Pendapatan Tahun ket }-1}-1\right) \times 100 \%
$$

\section{Metode Analisis Data}

Penelitian ini menggunakan alat analisis Structural Equation Modeling (SEM) dengan metode alternatif yaitu Partial Least Square (PLS). Dalam penelitian ini, baik variabel independen (VAICTM) maupun variabel dependen (kinerja keuangan), keduanya dibangun dengan indikator formatif. Oleh karena itu, peneliti memilih menggunakan PLS karena program analisis lainnya (misalnya AMOS, Lisrel, dsb.) tidak mampu melakukan analisis atas laten variabel dengan indikator formatif (Ghozali, 2006).

Terdapat dua bagian analisis yang harus dilakukan dalam PLS, yaitu:

1. Menilai outer model atau measurement model

Oleh karena diasumsikan bahwa antar indikator tidak saling berkorelasi, maka ukuran internal konsistensi reliabilitas (cronbach alpha) tidak diperlukan untuk menguji 
reliabilitas konstruk formatif (Ghozali 2006). Hal ini berbeda dengan indikator refleksif yang menggunakan tiga kriteria untuk menilai outer model, yaitu convergent validity, composite reliability dan discriminant validity.

Lebih lanjut Ghozali (2006) menyatakan bahwa karena konstruk formatif pada dasarnya merupakan hubungan regresi dari indikator ke konstruk, maka cara menilainya adalah dengan melihat nilai koefisien regresi dan signifikansi dari koefisien regresi tersebut. Jadi, kita melihat nilai weight masing-masing indikator dan nilai signifikansinya. Nilai weight yang disarankan adalah di atas 0.50 dan T-statistic di atas 1.645 untuk $\alpha=0.05$ (one tailed).

2. Menilai Inner Model atau Structural Model.

Model struktural dievaluasi dengan menggunakan $R$-square untuk konstruk dependen, Stone-Geisser Q-square test untuk predictive relevance dan uji t serta signifikansi dari koefisien parameter jalur structural (Ghozali, 2006). Dalam menilai model dengan PLS dimulai dengan melihat $R$-square untuk setiap variabel laten dependen. Perubahan nilai $R$-square dapat digunakan untuk menilai pengaruh variabel laten independen tertentu terhadap variabel laten dependen apakah mempunyai pengaruh yang substantif. Pengaruh besarnya $\mathrm{f}^{2}$ dapat dihitung dengan rumus sebagai berikut (Ghozali, 2006):

$$
\mathrm{f}^{2}=\frac{\mathrm{R}^{2} \text { included }-\mathrm{R}^{2} \text { exwluded }}{1-\mathrm{R}^{2} \text { included }}
$$

Dimana $\mathrm{R}^{\mathbf{2}}$ included dan $\mathrm{R}^{\mathbf{2}}$ excluded adalah $\mathrm{R}$-square dari variabel laten dependen ketika prediktor variabel laten digunakan atau dikeluarkan di dalam persamaan struktural.

Gambar 1 adalah bentuk model pengujian hipotesis 1 (H1) dengan menggunakan PLS. Pada H1, variabel independen (VAIC ${ }^{\mathrm{TM}}$ ) dihubungkan dengan variabel dependen (company's performance) pada tahun yang sama (2007 dengan 2007; 2008 dengan 2008; dan 2009 dengan 2009).

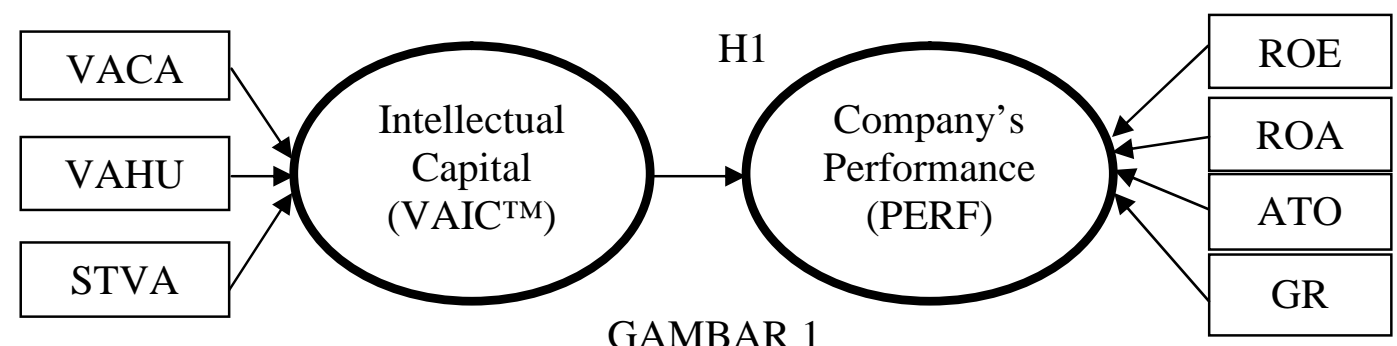

Model Pengujian dengan PLS untuk H1 
Model pengujian hipotesis $2(\mathrm{H} 2)$ dan hipotesis $3(\mathrm{H} 3)$ dengan menggunakan PLS ditunjukkan dalam gambar 2. Pada H2, variabel independen (VAIC ${ }^{\text {TM})}$ dihubungkan dengan variabel dependen (company's performance) dengan lag 1 tahun (2007 dengan 2008; 2008 dengan 2009). Demikian juga dengan H3, ROGIC 2007 dihubungkan dengan PERF 2008, dan ROGIC 2008 dihubungkan dengan PERF 2009

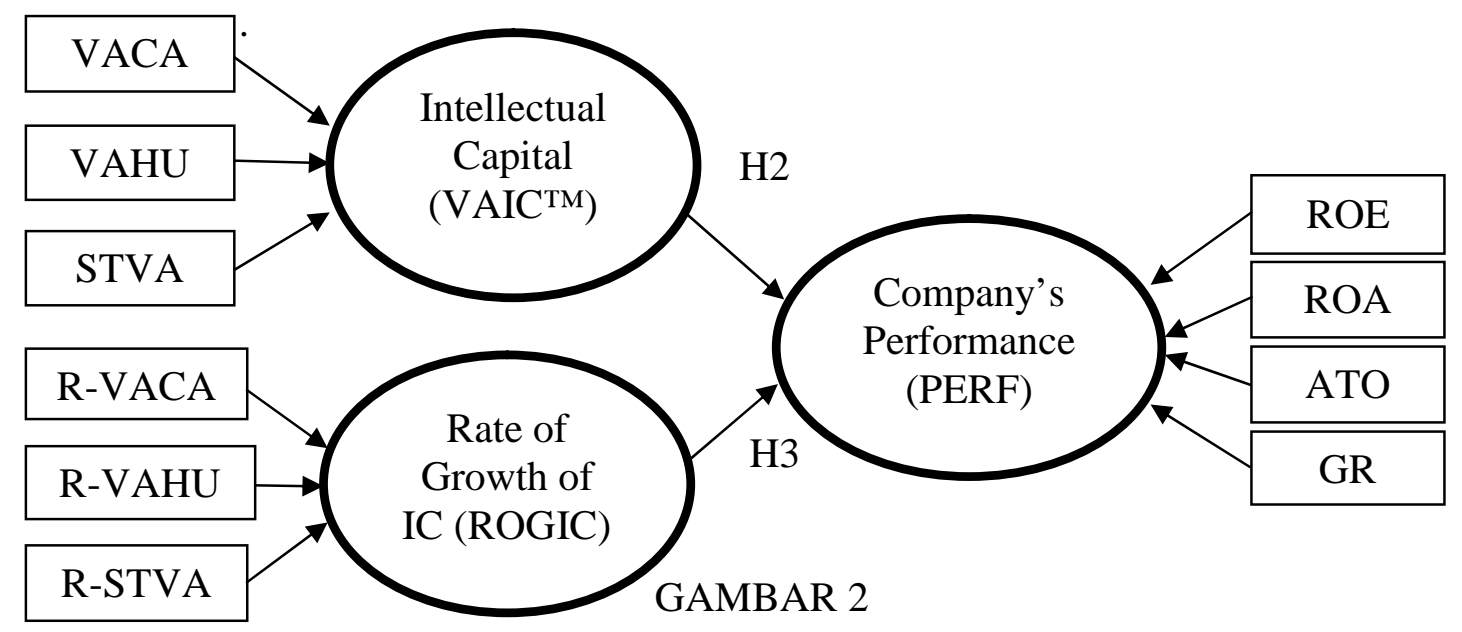

Model Pengujian dengan PLS untuk H2 dan H3

\section{Pengambilan Keputusan dengan PLS}

Pengambilan keputusan atas penerimaan atau penolakan hipotesis dilakukan dengan ketentuan sebagai berikut:

1. Melihat nilai outer weight masing-masing indikator dan nilai signifikansinya. Nilai weight yang disarankan adalah di atas 0.50 (positif) dan T-statistic di atas 1.282 untuk $\mathrm{p}$ $<0.10 ; 1.645$ untuk $\mathrm{p}<0.05$; dan 2.326 untuk $\mathrm{p}<0.01$ (one tailed). Indikator yang memiliki nilai di bawah ketentuan tersebut harus didrop dari model dan kemudian dilakukan pengujian ulang.

2. Melihat nilai inner weight dari hubungan antar variabel laten. Nilai weight dari hubungan tersebut harus menunjukkan arah positif dengan nilai T-statistic di atas 1.282 untuk $\mathrm{p}<0.10 ; 1.645$ untuk $\mathrm{p}<0.05$; dan 2.326 untuk $\mathrm{p}<0.01$ (one tailed).

3. Hipotesis alternatif (Ha) diterima jika nilai weight dari hubungan antar variabel laten menunjukkan arah positif dengan nilai T-statistic di atas 1.282 untuk $\mathrm{p}<0.10 ; 1.645$ untuk $\mathrm{p}<0.05$; dan 2.326 untuk $\mathrm{p}<0.01$. Sebaliknya, H0 gagal untuk ditolak jika nilai weight dari hubungan antar variabel laten menunjukkan arah negatif dan nilai T-statistic di bawah 1.282 untuk $\mathrm{p}<0.10 ; 1.645$ untuk $\mathrm{p}<0.05$; dan 2.326 untuk $\mathrm{p}<0.01$. 


\section{HASIL PENELITIAN DAN PEMBAHASAN}

\section{Hasil Penelitian}

\section{Sampel Penelitian}

Penelitian ini menggunakan Perusahaan manufaktur yang terdaftar di Bursa Efek Indonesia (BEI) periode tahun 2007-2009 sebagai populasi. Sampel dalam penelitian ini dipilih dengan menggunakan metode purposive sampling dengan tujuan untuk mendapatkan sampel yang representatif sesuai dengan kriteria yang telah ditentukan sebelumnya. Seleksi perusahaan sampel secara rinci dapat dilihat pada tabel 1 sebagai berikut :

\section{Tabel 1}

\section{Proses Perhitungan Sampel}

\begin{tabular}{|c|l|c|}
\hline No & \multicolumn{1}{|c|}{ Uraian } & Jumlah \\
\hline 1 & $\begin{array}{l}\text { Perusahaan manufaktur yang terdaftar di Bursa Efek Indonesia (BEI) } \\
\text { periode tahun 2007-2009. }\end{array}$ & 158 \\
\hline 2 & $\begin{array}{l}\text { Perusahaan yang tidak mempublikasikan LK tahunan berturut-turut } \\
\text { dari tahun 2007-2009 dan disajikan dalam bentuk Rupiah. }\end{array}$ & $(6)$ \\
\hline 3 & $\begin{array}{l}\text { Perusahaan melakukan merger atau akuisisi selama 3 tahun berturut- } \\
\text { turut yaitu 2007, 2008 dan 2009. }\end{array}$ & $(4)$ \\
\hline 4 & Perusahaan memperoleh laba negatif. & $(66)$ \\
\hline 5 & $\begin{array}{l}\text { Perusahaan sampel memperoleh ekuitas negatif selama periode } \\
\text { pengamatan. }\end{array}$ & $(26)$ \\
\hline 6 & Perusahaan disuspen dari perdagangan selama tahun 2007-2009. & $(3)$ \\
\hline 7 & Perusahaan layak untuk dijadikan sampel penelitian & 53 \\
\hline
\end{tabular}

Sumber : data diolah, 2011

Berdasarkan tabel 1 dapat diketahui bahwa jumlah perusahaan yang layak untuk dijadikan sampel penelitian dalam penelitian ini sebanyak 53 perusahaan.

\section{Statistik Deskriptif}

Statistik deskriptif variabel-variabel yang digunakan dalam penelitian dapat dilihat pada tabel 2 berikut:

\section{Tabel 2}

Statistik Deskriptif

\begin{tabular}{|l|c|r|r|r|r|r|}
\hline Variabel & N & Kisaran & Minimum & Maximum & \multicolumn{1}{c|}{ Mean } & Std. Deviation \\
\hline VACA & 159 & 26.387 & .302 & 26.689 & 2.216 & 2.363 \\
\hline VAHU & 159 & 319.082 & 3.108 & 322.190 & 35.337 & 39.608 \\
\hline STVA & 159 & .319 & .678 & .997 & .933 & .065 \\
\hline ROE & 159 & 3.234 & .002 & 3.236 & .190 & .295 \\
\hline ROA & 159 & .411 & .001 & .412 & .092 & .083 \\
\hline ATO & 159 & 2.999 & .243 & 3.243 & 1.293 & .500 \\
\hline GR & 159 & 4.892 & -.587 & 4.305 & .210 & .419 \\
\hline
\end{tabular}


Sumber : data diolah, 2011

Tabel 2 menunjukkan bahwa variabel VACA memiliki rata-rata sebesar 2.216 dengan nilai minimum sebesar 0.302 dan nilai maksimum sebesar 26.689, sedangkan standar deviasinya sebesar 2.363. VAHU memiliki rata-rata sebesar 35.337 dengan nilai minimum sebesar 3.108 dan nilai maksimum sebesar 322.190, sedangkan standar deviasinya sebesar 39.608. STVA memiliki rata-rata sebesar 0.933 dengan nilai minimum sebesar 0.678 dan nilai maksimum sebesar 0.997, sedangkan standar deviasinya sebesar 0.065. ROE memiliki rata-rata sebesar 0.190 dengan nilai minimum sebesar 0.002 dan nilai maksimum sebesar 3.236, sedangkan standar deviasinya sebesar 0.295.

Tabel 2 juga menunjukkan bahwa variabel ROA memiliki rata-rata sebesar 0.092 dengan nilai minimum sebesar 0.001 dan nilai maksimum sebesar 0.412 , sedangkan standar deviasinya sebesar 0.083. Variabel ATO memiliki rata-rata sebesar 1.293 dengan nilai minimum sebesar 0.243 dan nilai maksimum sebesar 3.243, sedangkan standar deviasinya sebesar 0.500. Variabel GR memiliki rata-rata sebesar 0.210 dengan nilai minimum sebesar -0.587 dan nilai maksimum sebesar 4.305, sedangkan standar deviasinya sebesar 0.419.

\section{Hasil Analisis}

Pengujian hiptotesis dalam penelitian ini dilakukan dengan menggunakan metode Partial Least Square (PLS). Tahap-tahap pengujian antara lain sebagai berikut :

\section{a. Uji Outer Model}

Oleh karena diasumsikan bahwa antar indikator tidak saling berkorelasi, maka ukuran internal konsistensi reliabilitas (cronbach alpha) tidak diperlukan untuk menguji reliabilitas konstruk formatif (Ghozali 2006). Hal ini berbeda dengan indikator refleksif yang menggunakan tiga kriteria untuk menilai outer model, yaitu convergent validity, composite reliability dan discriminant validity.

1) Uji Outer Model Hipotesis 1

Gambar 3 berikut ini merupakan hasil estimasi perhitungan dengan menggunakan PLS. 

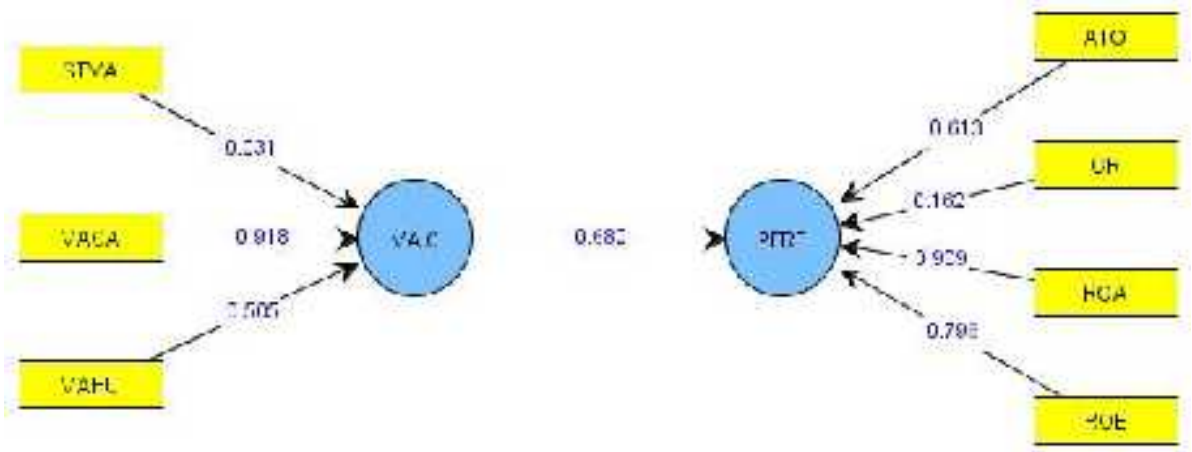

Gambar 3

Hasil Outer Model Hipotesis 1

Berdasarkan hasil pengujian dengan PLS sebagaimana ditunjukkan Gambar 3 di atas, diketahui bahwa dari 3 indikator yang membentuk VAIC, yang memiliki nilai t-statistics signifikan pada $\mathrm{p}<0.05$ hanya VACA dan VAHU. Sementara indikator-indikator untuk kinerja keuangan terdapat 3 variabel yang memiliki nilai tstatistics signifikan pada $\mathrm{p}<0.05$ yaitu ATO, ROA dan ROE. Untuk lebih detailnya dapat dilihat pada tabel 3 .

Tabel 3

Nilai Outer Weight Hipotesis 1

\begin{tabular}{|c|c|c|c|}
\hline Variabel & Weight & Standard deviation & t-Statistic \\
\hline VAIC & & & \\
\hline STVA & -0.031 & 0.138 & 0.225 \\
\hline VACA & 0.918 & 0.516 & 1.779 \\
\hline VAHU & 0.505 & 0.240 & 2.104 \\
\hline PERF & & & \\
\hline ATO & 0.613 & 0.306 & 2.003 \\
\hline GR & 0.162 & 0.157 & 1.032 \\
\hline ROA & 0.909 & 0.429 & 2.119 \\
\hline ROE & 0.796 & 0.471 & 1.690 \\
\hline
\end{tabular}

Sumber : data diolah, 2011

Berdasarkan tabel 3 diatas dapat diketahui bahwa terdapat indikator yang memiliki nilai weight rendah ( $<0.5$ positif) dan tidak signifikan (memiliki t-statistic <1.645) yaitu STVA dan GR, maka perlu dilakukan pengujian ulang dengan mengeliminasi indikator-indikator yang tidak signifikan dan atau hanya melibatkan indikator-indikator yang signifikan dan atau mendekati signifikan. Hasil pengujian ulang yang dilakukan ditunjukkan pada Gambar 4 sebagai berikut: 


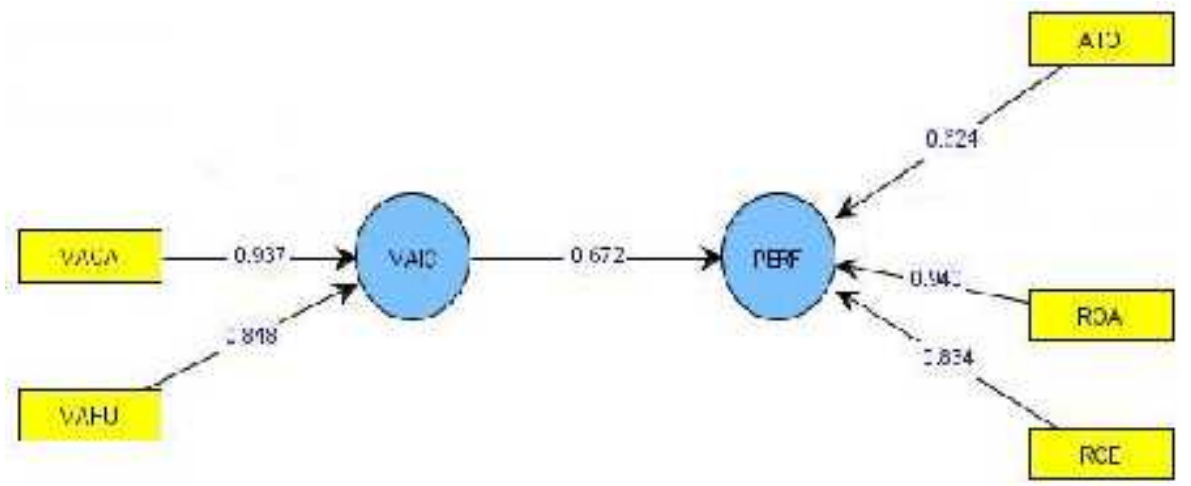

Gambar 4

Hasil Outer Model Hipotesis 1 (Recalculate)

Setelah menghilangkan indikator-indikator yang tidak signifikan dan hanya melibatkan indikator yang signifikan atau yang mendekati signifikan, maka dapat diketahui bahwa masing-masing variabel memiliki weight di atas 0.50 (positif) dan $\mathrm{t}$-statistics signifikan pada $\mathrm{p}<0.05$.

Tabel 5

Nilai Outer Weight Hipotesis 1 (Recalculate)

\begin{tabular}{|c|c|c|c|}
\hline Variabel & Weight & Standard deviation & T-Statistic \\
\hline VAIC & & & \\
\hline VACA & 0.937 & 0.520 & 1.802 \\
\hline VAHU & 0.848 & 0.187 & 4.535 \\
\hline PERF & & & \\
\hline ATO & 0.624 & 0.296 & 2.108 \\
\hline ROA & 0.940 & 0.365 & 2.575 \\
\hline ROE & 0.834 & 0.469 & 1.778 \\
\hline
\end{tabular}

Sumber : data diolah, 2011

Berdasarkan tabel 5 tampak bahwa model telah fit, karena masing-masing variabel memiliki weight $>0.5$ dan t-statistik $>1.645$.

2) Uji Outer Model Hipotesis 2 dan 3

Hipotesis ini untuk menguji pengaruh IC (VAIC) terhadap kinerja keuangan masa depan. Dalam hal ini diduga bahwa IC (VAIC) dapat digunakan sebagai alat untuk memprediksi kinerja keuangan perusahaan. Komponen-komponen VAIC tahun 2004 dan komponen-komponen ROGIC dihubungkan dengan ukuran-ukuran kinerja keuangan tahun 2005. Secara grafis, hasil pengujian dapat ilihat pada gambar 5 sebagai berikut : 


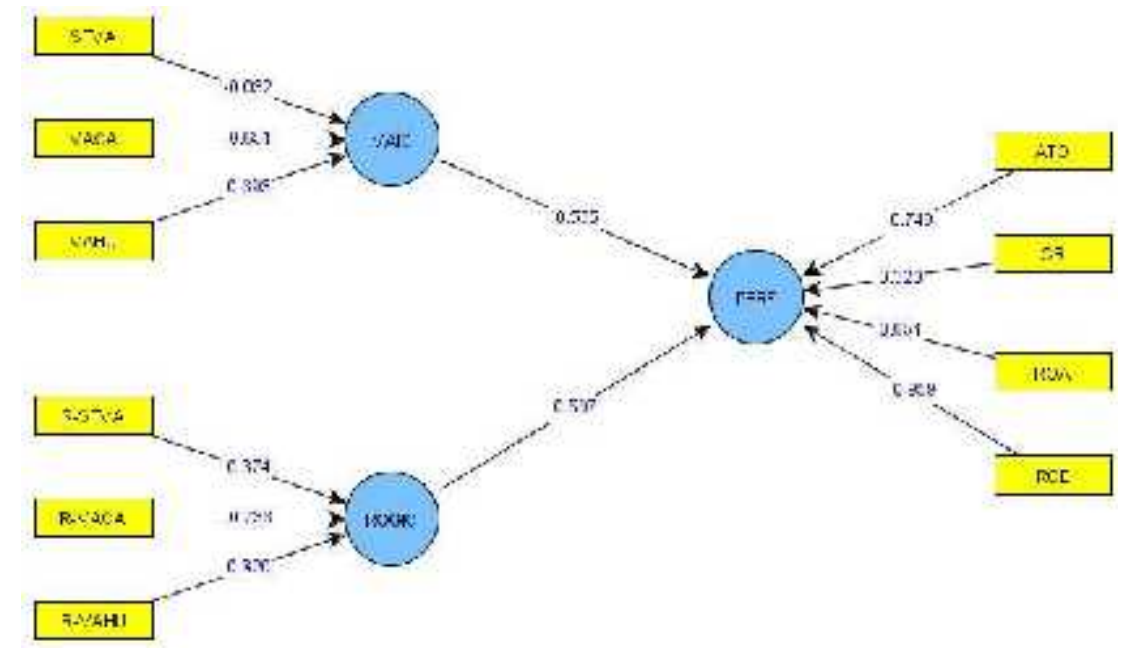

Gambar 5

Hasil Outer Model Hipotesis 2 dan 3

Berdasarkan hasil pengujian dengan PLS sebagaimana ditunjukkan gambar di atas diketahui bahwa terdapat beberapa indikator-indikator yang membentuk VAIC dan ROGIC memiliki nilai weight $<0.5$ dan t-statistics tidak signifikan.

Demikian pula dengan indikator-indikator kinerja keuangan (PERF). Tabel 6 di bawah ini menyajikan data yang lebih detail hasil pengujian.

Tabel 6

Nilai Outer Weight Hipotesis 2 dan 3

\begin{tabular}{|c|c|c|c|}
\hline Variabel & Weight & Standard deviation & T-Statistic \\
\hline VAIC & & & \\
\hline STVA & -0.032 & 0.304 & -0.105 \\
\hline VACA & 0.651 & 0.375 & 1.736 \\
\hline VAHU & 0.693 & 0.382 & 1.814 \\
\hline ROGIC & & & \\
\hline R-STVA & 0.374 & 0.244 & 1.533 \\
\hline R-VACA & 0.736 & 0.251 & 2.932 \\
\hline R-VAHU & 0.820 & 0.432 & 1.898 \\
\hline PERF & & & 3.420 \\
\hline ATO & 0.749 & 0.219 & 0.724 \\
\hline GR & 0.320 & 0.442 & 2.247 \\
\hline ROA & 0.654 & 0.291 & 1.740 \\
\hline ROE & 0.959 & 0.551 & \\
\hline Sum $:$ & & & \\
\hline
\end{tabular}

Sumber : data diolah, 2011

Berdasarkan tabel 6 diatas dapat diketahui bahwa terdapat indikator yang memiliki nilai weight rendah dan tidak signifikan (STVA, R-STVA dan GR), maka perlu dilakukan pengujian ulang terhadap indikator-indikator yang memiliki nilai t- 
statistics mendekati signifikan dengan mempertimbangkan hasil pengujian $\mathrm{H}$. Hasilnya disajikan pada gambar 6.

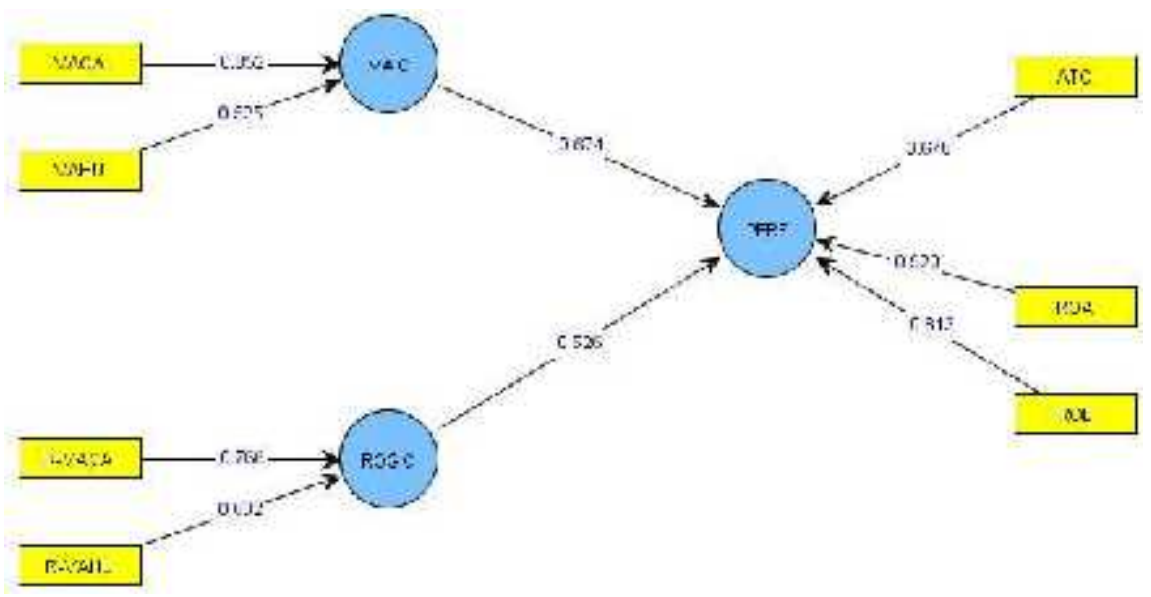

Gambar 6

Hasil Outer Model Hipotesis 2 dan 3 (Recalculate)

Secara lebih rinci hasil pengujian ulang dapat dilihat pada tabel 7 sebagai beirkut:

Tabel 7

Nilai Outer Weight Hipotesis 2 dan 3

\begin{tabular}{|c|c|c|c|}
\hline Variabel & Weight & $\begin{array}{c}\text { Standard } \\
\text { deviation }\end{array}$ & T-Statistic \\
\hline VAIC & & & \\
\hline VACA & 0.852 & 0.427 & 1.995 \\
\hline VAHU & 0.525 & 0.243 & 2.160 \\
\hline ROGIC & & & \\
\hline R-VACA & 0.766 & 0.409 & 1.873 \\
\hline R-VAHU & 0.632 & 0.294 & 2.150 \\
\hline PERF & & & \\
\hline ATO & 0.678 & 0.333 & 2.036 \\
\hline ROA & 0.920 & 0.461 & 1.996 \\
\hline ROE & 0.813 & 0.422 & 1.927 \\
\hline
\end{tabular}

Sumber : data diolah, 2011

b. Uji Inner Model

Pengujian inner model atau model struktural dilakukan untuk melihat hubungan antara konstruk, nilai signifikansi dan R-square dari model penelitian. Model struktural dievaluasi dengan menggunakan R-square untuk konstruk dependen, Stone-Geisser Qsquare test untuk predictive relevance dan uji t serta signifikansi dari koefisien parameter jalur struktural. 
Tabel 8

Nilai R-Square

\begin{tabular}{|l|c|c|}
\hline \multirow{2}{*}{\multicolumn{1}{|c|}{ Variabel }} & \multicolumn{2}{c|}{ R Square } \\
\cline { 2 - 3 } & Hipotesis 1 & Hipotesis 2 dan 3 \\
\hline VAIC & - & - \\
\hline PERF & 0.451 & 0.455 \\
\hline
\end{tabular}

Sumber : data diolah, 2011

Berdasarkan Tabel 8 di atas menunjukkan bahwa nilai R-square PERF untuk Hipotesis 1 adalah 0.451, artinya variabel VAIC mampu menjelaskan variabel PERF sebesar 45.1\%. nilai R-square PERF untuk Hipotesis 2 dan 3 adalah 0.455, artinya variabel VAIC mampu menjelaskan variabel PERF sebesar 45.5\%. Semakin besar angka R-square menunjukkan semakin besar variabel independen tersebut dapat menjelaskan variabel dependen, sehingga semakin baik persaman struktural.

Signifikansi parameter yang diestimasi memberikan informasi mengenai hubungan antar variabel-variabel penelitian. Dalam konteks ini, batas untuk menolak dan menerima hipotesis yang diajukan adalah di atas 1.282 untuk $\mathrm{p}<0.10 ; 1.645$ untuk $\mathrm{p}<0.05$; dan 2.326 untuk $\mathrm{p}<0.01$. Tabel 9 berikut ini menyajikan output estimasi untuk pengujian model struktural.

\section{Tabel 9}

Nilai Inner Weights

\begin{tabular}{|c|c|c|c|}
\hline & $\begin{array}{c}\text { original sample } \\
\text { estimate }\end{array}$ & $\begin{array}{l}\text { Standard } \\
\text { deviation }\end{array}$ & T-Statistic \\
\hline VAIC -> PERF & 0.672 & 0.334 & 2.012 \\
\hline VAIC $_{t} \rightarrow$ PERF $_{t+1}$ & 0.674 & 0.292 & 2.308 \\
\hline ROGIC -> PERF & 0.526 & 0.272 & 1.934 \\
\hline
\end{tabular}

Sumber : data diolah, 2011

Dari tabel 8 dan 9 di atas dapat diketahui bahwa H1, H2 dan H3 secara utuh diterima. Artinya, IC berpengaruh terhadap kinerja perusahaan, baik kinerja saat ini maupun kinerja masa depan. Selain itu, pertumbuhan IC terhadap kinerja keuangan masa depan juga berpengaruh signifikan pada alfa $5 \%$.

\section{Pembahasan}

Berdasarkan hasil pengujian PLS sebagaimana telah dijabarkan di atas, pembahasan disajikan dalam dua bagian. Bagian pertama membahas pengaruh IC (VAIC) terhadap kinerja keuangan perusahaan, baik kinerja tahun berjalan (H1) maupun kinerja di masa mendatang (H2). Sedangkan bagian kedua membahas pengaruh rata-rata pertumbuhan IC (rate of growth of $I C$ - ROGIC) terhadap kinerja keuangan perusahaan masa depan (H3). 
a. Pengaruh Intellectual Capital (VAIC) terhadap Kinerja Keuangan Perusahaan (H1 \& $\mathrm{H} 2)$

Hipotesis pertama yang diajukan dalam penelitian ini adalah bahwa IC (VAIC) berpengaruh terhadap kinerja keuangan perusahaan. Dalam konteks ini, IC diuji terhadap kinerja keuangan perusahaan pada tahun yang sama.

Tabel 9 membuktikan bahwa nilai t-statistics path antara VAIC dan PERF sebesar 0.672 dengan t-statistic sebesar 2.012 (di atas 1.645). Hal ini berarti loading-nya signifikan pada $\mathrm{p}<0.05$ (1-tailed) dan mengindikasikan adanya pengaruh positif signifikan IC (VAIC) terhadap kinerja keuangan perusahaan. Nilai R-square sebesar 0.451. Hal ini menunjukkan bahwa kekuatan IC (VAIC) dalam menjelaskan variabel kinerja keuangan adalah sebesar 45.1 persen, sehingga dengan demikian maka berarti H1 diterima.

Temuan ini konsisten dan mendukung temuan Tan et al. (2007) dan Chen et al. (2005), serta secara parsial mendukung temuan Firer dan Williams (2003) dan Ulum (2007). Bukti yang disajikan oleh Tan et al. (2007) dan Chen et al. (2005) menyatakan bahwa tiga komponen VACA, VAHU, dan STVA secara statistik signifikan untuk menjelaskan konstruk VAIC dan juga signifikan berpengaruh terhadap kinerja keuangan perusahaan. Sementara hasil penelitian ini memberikan bukti bahwa hanya VACA dan VAHU yang secara statistik signifikan berpengaruh terhadap kinerja keuangan selama tiga tahun pengamatan. Sementara itu, indikator ATO, ROA dan ROE yang secara statistik dapat mewakili konstruk kinerja keuangan.

Hipotesis kedua yang diajukan dalam penelitian ini adalah bahwa IC (VAIC) berpengaruh secara positif terhadap kinerja keuangan perusahaan masa depan. Artinya, IC digunakan sebagai alat untuk memprediksi kinerja keuangan perusahaan di masa mendatang. Dalam konteks ini, IC diuji terhadap kinerja keuangan perusahaan dengan lag 1 tahun.

Berdasarkan tabel Tabel 9 dapat diketahui bahwa nilai t-statistics path antara VAIC $_{t}$ dan PERF ${ }_{t+1}$ adalah sebesar 2.308 (di atas 1.645) yang signifikan pada alfa 5\%. Hal ini mengindikasikan adanya pengaruh positif signifikan IC (VAIC) terhadap kinerja keuangan perusahaan masa depan. Nilai R-square sebesar 0.455 yang menunjukkan bahwa IC (VAIC) mampu menjelaskan variabel kinerja keuangan masa depan sebesar 45.5 persen. Sehingga dengan demikian maka berarti H2 diterima. 
Temuan ini konsisten dan mendukung temuan Tan et al. (2007), Chen et al. (2005) dan Ulum (2007) yang juga dapat membuktikan bahwa IC (VAIC) berpengaruh positif signifikan terhadap kinerja keuangan perusahaan masa depan. Bukti yang disajikan oleh Tan et al. (2007) dan Chen et al. (2005) menyatakan bahwa tiga komponen VACA, VAHU, dan STVA secara statistik signifikan untuk menjelaskan konstruk VAIC dan juga signifikan berpengaruh terhadap kinerja keuangan perusahaan masa depan. Sementara hasil penelitian ini memberikan bukti bahwa hanya VACA dan VAHU yang secara statistik signifikan berpengaruh terhadap kinerja keuangan masa depan.

Sementara itu, hanya indikator profitabilitas ATO, ROA dan ROE yang secara statistik dapat mewakili konstruk kinerja keuangan. Hal ini berarti bahwa dari ketiga komponen VAIC, hanya VACA dan VAHU yang secara siginifikan dapat dijadikan sebagai alat untuk memprediksi kinerja keuangan perusahaan masa depan.

Secara umum, hasil pengujian terhadap $\mathrm{H} 1$ dan $\mathrm{H} 2$ penelitian ini relatif sama dengan temuan Firer dan Williams (2003) untuk kasus perusahaan publik di Afrika Selatan. Persamaan yang dimaksud adalah bahwa (1) tidak seluruh komponen VAIC memiliki pengaruh signifikan terhadap kinerja keuangan perusahaan, dan (2) bahwa tidak semua ukuran kinerja keuangan yang digunakan berkorelasi dengan komponenkomponen VAIC, hanya VACA dan VAHU yang secara statistik signifikan berhubungan positif dengan ukuran kinerja keuangan perusahaan.

Sementara hasil penelitian ini menunjukkan bahwa hanya VACA dan VAHU yang secara statistik signifikan untuk menjelaskan konstruk VAIC, dan hanya ATO, ROA dan ROE yang signifikan untuk menjelaskan variabel kinerja keuangan perusahaan. Rasionalisasi yang dapat diberikan untuk menjelaskan temuan ini adalah:

Secara umum dalam tiga tahun pengamatan, value added terbesar yang dimiliki perusahaan dihasilkan oleh efisiensi dari capital employed dan human capital. Artinya, perusahaan manufaktur di Indonesia telah berhasil "memanfaatkan" dan memaksimalkan dana yang tersedia (ekuitas dan laba bersih) serta keahlian, pengetahuan, jaringan, dan olah pikir karyawannya untuk menciptakan nilai bagi perusahaan.

2)

Hasil pengujian menunjukkan bahwa VACA dan VAHU memiliki nilai tstatistik signifikan untuk menjelaskan konstruk VAIC. Hasil penelitian menunjukkan 
bahwa intellectual ability suatu perusahaan dibangun oleh physical capital (VACA) dan intellectual potential (VAHU).

Hasil pengujian juga menunjukkan bahwa rasio profitabilitas yang terdiri dari ATO, ROA dan ROE memiliki nilai t-statistik signifikan untuk menjelaskan konstruk PERF. Hasil penelitian menunjukkan bahwa kinerja keuangan perusahaan dapat diproksikan pada ATO, ROA dan ROE.

b. Pengaruh Rata-rata Pertumbuhan Intellectual Capital (ROGIC) terhadap Kinerja Keuangan Perusahaan Masa Depan (H3)

Hipotesis ketiga yang diajukan dalam penelitian ini adalah ada pengaruh positif rata-rata pertumbuhan Intellectual capital terhadap kinerja keuangan perusahaan masa depan. Hipotesis ini mengacu pada penelitian Tan et al. (2007) yang melogikakan bahwa jika IC dapat berpengaruh terhadap kinerja keuangan perusahaan masa depan, maka rata-rata pertumbuhan IC (ROGIC) juga akan berpengaruh terhadap kinerja keuangan perusahaan masa depan.

Berdasarkan tabel 9 dapat diketahui Path antara ROGIC dan PERF memiliki nilai t-statistics sebesar 1.934 (diatas 1.645), berarti signifikan pada $\mathrm{p}<0.05$ (1-tailed). Hal ini mengindikasikan adanya pengaruh positif signifikan ROGIC terhadap kinerja keuangan perusahaan masa depan. Sehingga dengan demikian maka berarti H3 dapat diterima.

Temuan penelitian ini mendukung penelitian Tan et al. (2007) yang menunjukkan adanya pengaruh signifikan ROGIC terhadap kinerja keuangan masa depan. Hal ini berarti bahwa perusahaan telah secara maksimal mengelola dan mengembangkan kekayaan intelektualnya untuk meningkatkan kinerja keuangannya.

\section{SIMPULAN}

Penelitian ini bertujuan untuk menganalisis Pengaruh Intellectual Capital Terhadap Kinerja Keuangan Perusahaan. Berdasarkan pembahasan dan analisis data dari, maka dapat ditarik beberapa kesimpulan sebagai berikut: Pertama, Ada pengaruh positif Intellectual capital (VACA, VAHU, dan STVA) terhadap kinerja keuangan perusahaan (Return on Equity, Return on Total Assets, Asset Turn Over, dan Growth Revenue). Hasil ini dibuktikan dengan nilai t-statistics path antara VAIC dan PERF sebesar 2.012 (di atas 1.645). Kedua, ada pengaruh positif Intellectual capital (VACA, VAHU, dan STVA) terhadap kinerja keuangan perusahaan masa depan. Hasil ini dibuktikan dengan nilai t-statistics path antara 
VAIC $_{\mathrm{t}}$ dan PERF $_{\mathrm{t}+1}$ adalah sebesar 2.308 (di atas 1.645). Ketiga, ada pengaruh positif ratarata pertumbuhan Intellectual capital terhadap kinerja keuangan perusahaan masa depan. Hasil ini dibuktikan dengan nilai t-statistics path antara ROGIC dan PERF adalah sebesar 1.934 (di atas 1.645).

Berdasarkan uraian pada bab-bab sebelumnya, sebagai suatu bahan pertimbangan dan sebagai bahan telaah bagi pihak-pihak yang berkepentingan adalah sebagai berikut: Pertama, penelitian yang akan datang diharapkan dapat menggunakan variabel lain sebaai proxy kinerja keuangan perusahaan, misalnya market to book value, market capitalization dan EPS. Sehingga didapatkan hasil yang berbeda untuk memperkaya referensi atas penelitian yang berkaitan dengan kinerja keuangan perusahaan. Kedua, penelitian ini hanya menggunakan lag 1 untuk memprediksi pengaruh IC terhadap kinerja keuangan pada masa depan. Pada penelitian selanjutnya diharapkan dapat menggunakan lag 2 atau 3 tahun, karena ada kemungkinan IC berpengaruh pada kinerja keuangan perusahaan pada 2 atau 3 tahun yang akan datang.

\section{DAFTAR PUSTAKA}

Abdolmohammadi, M. J. 2005. Intellectual Capital Disclosure and Market Capitalization. Journal of Intellectual Capital, Vol. 6 No. 3, pp. 397-416.

Astuti, P. D. dan A. Sabeni.. 2005. Hubungan Intellectual Capital dan Business Performance. Dengan Diamond Specification: Sebuah Perspektif Akuntansi, Makalah dipresentasikan, SNA VIII, Solo, 15-16 September 2005, pp. 694-707.

Firer, S., and S.M. Williams. 2003. Intellectual Capital and Traditional Measures of Corporate Performance, Journal of Intellectual Capital, Vol. 4 No. 3, pp. 348360 .

Guthrie, J., and L.D. Parker. 1989. Corporate Social Reporting: A Rebuttal of Legitimacy Theory, Accounting and Business Research, Vol. 19 No.76.

Harrison, S., and P.H. Sullivan. 2000. Profitting Form Intellectual Capital; Learning From Leading Companies, Journal of Intellectual Capital, Vol. 1 No. 1, pp. 33-46.

Ihyaul, Ulum. 2010 Intellectual Capital Corner/Value Added Intellectual Coefficient (VAIC), online, http://ihyaul.staff.umm.ac.id/2010/03/value-added-intellectualcoefficient-vaic\%e2\%84\%a2/, diakses tanggal 17 Maret 2011.

Indriantoro dan Supomo. 2002. Metodologi Penelitian Bisnis Untuk Akuntansi dan Manajemen, Edisi Pertama, Yogyakarta: BPFE UGM. 
Kuryanto, Benny dan Muchamad Syafruddin. 2008. Pengaruh Modal Intelektual terhadap Kinerja Perusahaan, makalah dipresentasikan, Simposium Nasional Akuntansi XI, Ikatan Akuntan Indonesia Kompartemen Akuntan Pendidik, pp. 1-30.

Mavridis, D. G. 2004. The Intellectual Capital Performance of The Japanese Banking Sector, Journal of Intellectual Capital, Vol. 5 No. 3. pp. 92-115.

Pardede, Fernando. 2010. Relationship Analysis Of Financial Performance Intellectual Capital Insurance Company in Indonesia Stock Exchange, online, http://www.gunadarma.ac.id, diakses tanggal 17 Maret 2011.

Pramelasari, Y. M. 2010. Pengaruh Intellectual Capital Terhadap Nilai Pasar dan Kinerja Keuangan Perusahaan, Skripsi, Dipublikasikan, Semarang, Fakultas Ekonomi Universitas Diponegoro Semarang.

Sawarjuwono, T. 2003. Intellectual Capital: Perlakuan, Pengukuran, dan Pelaporan (Sebuah library research), Jurnal Akuntansi dan Keuangan, Vol. 5 No. 1, pp. 3557.

Solikhah, B. 2010. Implikasi Intellectual Capital Terhadap Kinerja Keuangan, Pertumbuhan, dan Nilai Pasar Pada Perusahaan Yang Tercatat di Bursa Efek Indonesia, Tesis, Dipublikasikan, Semarang, Program Pascasarjana Magister Sain, Universitas Diponegoro Semarang.

Ulum, Ghozali, dan Chariri. 2008. Intellectual Capital dan Kinerja Keuangan Perusahaan; Suatu Analisis Dengan Pendekatan Partial Least Squares, Makalah dipresentasikan, Simposium Nasional Akuntansi XI, Ikatan Akuntan Indonesia Kompartemen Akuntan Pendidik, Pontianak, pp. 1-31.

Yusup, 2009, Intellectual Capital and Market Performance on Companies Listed in Indonesia Stock Exchange, online, http://www.gunadarma.ac.id, diakses tanggal 17 Maret 2011. 